\title{
Forensic Toxicology Research to Investigate Environmental Hazard
}

\author{
Reena C Jhamtani, M.S. Dahiya and Rakhi Agarwal* \\ Laboratory of Molecular and Analytical Toxicology (Forensic Chemistry \& Toxicology Laboratory), Institute of Forensic Science, Gujarat Forensic Sciences \\ University, Gandhinagar, Gujarat, India
}

Submission: April 19, 2017; Published: May 24, 2017

*Corresponding author: Rakhi Agarwal, Laboratory of Analytical \& Molecular Toxicology (Forensic Chemistry and Toxicology Laboratory), Institute of Forensic Science, Gujarat Forensic Sciences University Sector 09, Gandhinagar- 382007, Gujarat, India, Tel: (0) 079 23977146; Email: reenajhamtani@gmail.com; lamt.dct.gfsu@gmail.com

Abstract

Forensic toxicology focuses on medico-legal aspects of chemical exposure and toxic injury on living organism and an environmental hazard i.e. a substance, state or event which has the potential to threaten the natural environment and / or adversely affect people's health. For instance, aldrin: a cyclodiene-organochlorine pesticide, is classified as persistent organic pollutant (POP). The use of aldrin has been banned long ago but still it is detected in ecosystem in its biotransformed form i.e. dieldrin (metabolite of aldrin) in the quantity higher than acceptable limits. Present editorial provides a baseline data on aldrin toxicity.

\section{Introduction}

Poisoning occurs when any substance interferes with normal body functions after it is swallowed, inhaled, injected, or absorbed. The branch of medicine that deals with the detection and treatment of poisons is known as toxicology. Broadly, toxicology is the study of the adverse effects of chemical or physical agents on living organisms. Forensic toxicology is the use of toxicology and other disciplines such as analytical chemistry, pharmacology and clinical chemistry to aid medical or legal investigation of death due to poison and drug. The primary concern for forensic toxicology is not only the legal outcome of the toxicological investigation or the technology utilized, but the obtainment and interpretation of results. For example: Aldrin (hexachlorohexahydrodimethanonapthalene), a broad spectrum insecticide belonging to cyclodiene class of organochlorine pesticide, is almost immediately metabolized into another substance dieldrin, requires detailed investigation of factors such as source of exposure and chemical purity concentration necessary to confirm diagnosis of aldrin poisoning. The substance may also have been diluted by its dispersal through the body. A blood sample of approximately $05 \mathrm{ml}$ is usually sufficient to screen and confirm most common toxic substances, which provides a profile of the substance to the toxicologist [1].

In today's society, human direct or indirect human exposure to some sort of chemicals is obvious. Firstly, the general concern of environmental pollution is due to use of chemical substances. Likewise, contaminated food and drink are the main concern throughout the world. Among toxic substance, pesticides characterize potentially grievous vulnerability to human wellbeing [2]. As known, all pesticides are toxic pollutants though; all pollutants are not toxic pesticides. Pesticides are classified as organochlorines, organophosphates, carbamates and pyrethroids. Pesticide in relation to human-health led to two periphery concerns. Firstly the concentration at which it cause toxicity or is poisonous and other being its relative toxicity to other pesticides. The pesticide varies greatly in their toxicity and persistence [3]. The nature of chemical substance suggests the possibility of functional disturbances in a target organ.

Poisoning may be intentional viz. homicidal and suicidal or unintentional viz. accidental (survival or fatal) and occupational (survival with side effects). Curiosity, inability to read warning labels, inadequate supervision mental confusion, poor eyesight, and the use of multiple drugs are the leading reasons for high rate of accidental poisoning. A substantial number of poisonings also occur as suicide attempts or drug overdoses. For instance, in 2016, Arizona department of health sciences evaluated dieldrin in crawl space dirt on the request by residents to be in concentration of $0.88 \mathrm{ppm}$ i.e. higher than acceptable limit. It may be ingested, inhalated and cause potential exposure to residents at place. A news by Japan times in 2015 reported dumping of 
whale meat imported from Norway as its consists of aldrin and dieldrin higher than safety limits of $0.1 \mathrm{ppm}$. Bhadouria et al. discussed in study the current use of aldrin in Kaldeo National park, Bharatpur Rajasthan in India and detected 0.1173 ppm of dieldrin [4].

Aldrin is prepared by Diels-Alder reaction. It has the empirical formula C12H8Cl6O and molecular mass $364.90 \mathrm{~g} / \mathrm{ml}$. Aldrin was first introduced in 1950's. It is classified by WHO as Class $2 \mathrm{~B}$, highly hazardous chemical. It is highly toxic in nature, classified as persistent-organic-pollutant (POP). Aldrin is one of the hazardous occupational and environmental pollutants arising primarily in ecosystem since precedent usage [5]. Aldrin has often been formulated as seed dressing and its principle use has been against soil insects that attack field, forage, vegetables and food crop. The main use of dieldrin was soil treatment including termite eradication but has been used in homes widely against vectors of disease including malaria in the tropic and spot treatment in temperate zone [6]. It is bio-accumulative, persistent (remaining up to 3 decades after use) and toxic in nature.

Although, it is banned long-ago, the past anthropogenic activities (where it was previously used) have led to detection of dieldrin into the environment at concentrations significantly higher than acceptable limits [7]. This owes to its high lipophilic properties, low volatility and resistance to degradation by physical and biological processes [8]. Its accumulation has elicited worldwide concern for many reasons.

Several monitoring studies globally have been carried out to investigate impact of aldrin and dieldrin residues on water, sediment and biota. It is commonly traceable in nature as reported by many researchers [9-11]. Aldrin released to the environment and gets readily converted to dieldrin. The conversion of aldrin to dieldrin occurs much more rapidly than the subsequent biotransformation and elimination of dieldrin, resulting in the accumulation of dieldrin in lipid rich tissues.

Aldrin is ubiquitous toxic pesticide, a potent inhibitor of gamma amino butyric acid type A receptor, tert-butylbicyclophosphorothionate (GABAA-TBPS) binding site [12-14] that disrupts gabarnergic signaling by preventing chloride influx into the $\operatorname{GABA}(\mathrm{A})$ receptor ionophore complex $[5,14,15]$. Thus, facilitates excitatory neurotransmitter release or interferes with inhibitory neurotransmitter action. It has a serious toxicity in humans and animals causing CNS manifestations like: neurotoxic effects with onset of seizures, instability and excitation $[5,12]$.

On acute toxicity, respiratory difficulties [16], sluggishness, anemia, carcinogenicity, atrophy, decrease red blood cell count and reduced hemoglobin concentration have been observed. It is also found to be genotoxic [17]. Renal toxicity has been reported in humans and animals on acute [18], intermediate duration $[19,20]$ and chronic exposure [21,22]. The liver is the most sensitive target of toxicity in intermediate duration exposure $[19,23,24]$ and chronic-duration studies as in rats $[22,25]$. The adaptive changes in the liver have been observed in acutely exposed animals [26].

Aldrin has extremely long half-life in the human body and is highly cumulative in fats such as brain [27]. The liver plays primary roles in the metabolism and excretion of xenobiotics with morphological alterations occurring in some toxic conditions [28]. In consideration divalent oxygen play important role in metabolism process which involves oxidative enzymes. In brain, metabolic enzymes for several xenobiotics have been characterized. It has been reported that aldrin starts converting to by-product dieldrin by epoxidation process on metabolism in liver tissue in fish after 8 hours exposure and reached $94 \%$ in 32 days [29] and can be distributed in organisms through blood stream. Dieldrin conjugation for its excretion occurs mainly in liver however dieldrin can be created outside the liver which would have a greater chance of causing toxic effects. Aldrin metabolism involves the major role of mixed function oxidase (MFO) activity in fish [30].

Being toxic to many species of animals, aldrin toxicity relies on many factors such as animal weight [31], time / duration of exposure [32] and temperature [3]. Literature reported shows that (lethal dose) LD50 for Rana hexadactyla under aldrin was found to be $2.4 \mathrm{ppm}$ [33]. In fish, Saccobranchus fossilus was found to be $0.44 \mathrm{ppm}$. Aldrin on comparison to other organochlorine is found to be less toxic than drins (isodrin, endrin and dieldrin) while more toxic than D.D.T, endosulphan, heptachlor, lindane and chlordane [21,34].

It has been reported median tolerance limit for fish exposure to aldrin concentration ranging from $0.089 \mathrm{ppb}$ to $0.018 \mathrm{ppm}$ at 24 hours. Singh et al. found that increased levels of magnesium and phosphate in blood plasma were related to diminish entrance of calcium through damage gills of fish exposed to aldrin[35]. Aldrin affects the growth and vital functions of zebra fish at very low $(0.01 \mu \mathrm{g} / \mathrm{l})$ concentrations [21]. During zebra fish development dieldrin causes apoptosis, disorganized motor neuron axon formation and significant damage of dopamine nerve cells in the brain [36]. Aldrin exposure causes oxidative stress in zebra fish indicated by increase in MDA level, decrease in superoxide dismutase activity and gene expression at sublethal concentrations. [37-39]. Lipodosis occur in liver on exposure to OCP's in the eel Anguilla Anguilla [40]. Exposure to dieldrin disrupts reproductive processes in teleost fish and a high level of GABA is found in hypothalamus and cerebellum [5].

In rats, acute oral toxicity dose of aldrin is $20-70 \mathrm{mg} / \mathrm{kg}$ while increase in body weight and mortality was observed with repeated dose at $300 \mathrm{ppm}$ of aldrin. The estimated lethal dose for man is approximately $5 \mathrm{~g}$ in human, blood concentrations exceeded $20 \mu \mathrm{g} / 100 \mathrm{ml}$ in exposed patients showing signs of aldrin intoxication [41]. 


\section{Conclusion}

Aldrin and dieldrin clearly affects food chain. Mechanisms of effect would be better understood if there was more central data collection reporting systems. There is a biologic gap in the research on aldrin and dieldrin toxicity. The relationship of environmental exposure and public health is now becoming a very active field of research. It is apparent from the data sources reported that dieldrin remains in the environment at high levels on aldrin exposure; therefore, it raises significant issues for public health. Tools to find and use information are rapidly improving. Aldrin and dieldrin has been used in this review as a pathway in forensic toxicology research to investigate environmental hazard.

\section{Acknowledgement}

Ms. Reena C. Jhamtani is grateful to DST-INSPIRE, Department of Science and Technology, New Delhi, India for award of Junior and Senior Research Fellowships.

\section{References}

1. Lehman-McKeeman LD (2008) Absorption, distribution and excretion of toxicants. In Klaassen CD, ed. Casarett and Doull's toxicology: the basic science of poisons, 7th edn, Chap 5. New York (NY): McGraw-Hill, Health Professions Division pp: 131-160.

2. Cicchetti R, Argentin G (2003) The role of oxidative stress in the in vitro induction of micronuclei by pesticides in mouse lung fibroblasts. Mutagenesis 18(2):127-132.

3. Kerr SR, Vass WP (2013) Pesticides residue in aquatic invertebrates. Edwards CA, ed. Environmental pollution by pesticides. Plenum Press, London and New York. pp 31.

4. Bhadouria BS, Mathur VB, Kaul R (2012) Monitoring of organochlorine pesticides in and around Keoladeo National Park, Bharatpur, Rajasthan, India. Environ Monit Assess 184(9): 5295-5300.

5. Martyniuk CJ, Feswick A, Spade DJ, Kroll KJ, Barber DS, et al. (2010) Effects of acute dieldrin exposure on neurotransmitters and global gene transcription in largemouth bass (Micropterussalmoides) hypothalamus. Neurotoxicology 31(4): 356-366.

6. ATSDR (2002) Toxicological Profile for Aldrin. Atlanta, GA: Agency for Toxic Substances and Disease Registry, U.S. Department of Health and Human Services, Public Health Service, USA.

7. Jorgenson JL (2001) Aldrin and dieldrin: a review of research on their production, environmental deposition and fate, bioaccumulation, toxicology, and epidemiology in the United States. Environ. Health Perspect 109(1):113-139.

8. Ghosh R, Siddharth M, Singh N, Kare PK, Banerjee BD, et al. (2017) Organochlorine Pesticide-Mediated Induction of NADPH Oxidase and Nitric-Oxide Synthase in Endothelial Cell. J ClinDiag Res.

9. Singh C, Venkataramegowda S (2015) Organochlorine Residues in Bees and Hive Products in Karnataka. Int J Sci Res 4(5): 1954-1960.

10. Devi NL, Yadav IC, Raha P, Shihua Q, Dan Y (2015) Spatial distribution, source apportionment and ecological risk assessment of residual organochlorine pesticides (OCPs) in the Himalayas. Environ Sci Pollut Res Int 22(24): 20154-20166.

11. Chopra AK, Sharma MK, Chamoli S (2011) Bioaccumulation of organochlorine pesticides in aquatic system-an overview. Environ Monit Assess 173(1-4): 905-916.
12. Costa LG (2015) The neurotoxicity of organochlorine and pyrethroid pesticides. In Occupational Neurology: Handb Clin Neurol 131(3): 135148.

13. Costa LG, Giordano G, Guizzetti M, Vitalone A. (2008) Neurotoxicity of pesticides: a brief review. Front Biosci 13(4):1240-1249.

14. Coats JR (1990) Mechanisms of toxic action and structure-activity Relationships for Organochlorine and Synthetic Pyrethroid Insecticides. Environ. Health Perspect 87: 255-262.

15. Bloomquist JR, Soderlund DM (1985) Neurotoxic insecticides inhibit GABA-dependent chloride uptake by mouse brain vesicles. Biochem. Biophys Res Commun 133(1): 37-43.

16. Matsumura F (1985) Classification of Insecticides- In Toxicology of Insecticides, 2nd edn. Chapter: 2 Springer US. Plenum Press, New York. Pp: 45-109.

17. Cicchetti R, Bari M, Argentin G (1999) Induction of micronuclei in bone marrow by two pesticides and their differentiation with CREST staining: an in vivo study in mice. Mutat Res 439(2): 239-248.

18. Spiotta EJ (1951) Aldrin poisoning in man; report of a case. Arch IndustHyg and Occupational Med 4(6): 560-566.

19. Ahmad N, Harsas W, Marolt RS, Morton M, Pollack KJ (1988) Total DDT and dieldrin content of human adipose tissue. Bull Environ Contam Toxicol 41(4): 802-808.

20. Bandyopadhyay SK, Tiwari RK, Bhattacharyya A, Chatterjee GC (1982) Effect of dieldrin on rat liver plasma membrane enzymes. Toxicol Lett 11(1-2):131-134.

21. Campagna AF, Eler MN, Fracácio R, Rodrigues BK, Verani NF (2007) The toxic potential of aldrin and heptachlor on Danio rerio juveniles (Cypriniformes, Cyprinidae). Ecotoxicol 16(3): 289-298.

22. Treon JF, Cleveland FP, Stemmer KL, et al. (1955b) The toxicity of aldrin when fed to suckling dogs, and the toxicity of aldrin, dieldrin, DDT and lindane when incorporated in the diets of older dogs over a period of more than fifteen months. Cincinnati, $\mathrm{OH}$. The Kettering Laboratory in the Department of Preventive Medicine and Industrial Health, College of Medicine, University of Cincinnati.

23. Treon JF, Dutra FR, Shaffer KL, et al. (1951a) The toxicity of aldrin, dieldrin, and DDT when fed to rats over the period of six months. Cincinnati, $\mathrm{OH}$. The Kettering Laboratory in the Department of Preventive Medicine and Industrial Health, College of Medicine, University of Cincinnati.

24. Treon JF, Dutra FR, Shaffer KL, et al. (1951b) The toxicity of aldrin and dieldrin when fed to dogs for variable periods. Cincinnati, $\mathrm{OH}$. The Kettering Laboratory in the Department of Preventive Medicine and Industrial Health, College of Medicine, University of Cincinnati.

25. Thorpe E, Walker AIT (1973) The toxicity of dieldrin (HEOD). II. Comparative long-term oral toxicology studies in mice with dieldrin, DDT, phenobarbitone, $\beta$-BHC and $\gamma$-BHC. Food Cosmet Toxicol 11: 433441.

26. Bano Y (1982) Effects of aldrin on serum and liver constituents of freshwater catfish Clarius batracus L. Proc Indian Acad Sci (Anim. Sci.) 91(1): 27-32.

27. Lamai SL, Warner GF, Walker CH. (1999) Effects of dieldrin on life stages of the African catfish, Clariasgariepinus (Burchell). Ecotoxicol Environ Saf 42: 22-29.

28. Rocha E, Monteiro RAF (1999) Histology and cytology of fish liver: A review. In Ichthyology: Recent research advances,Saksena D.N. (ed). Science Publishers, Enfield: New Hampshire.

29. Boyle HW, Burttschell R, Rosen AA (1966) Infrared Identification of chlorinated insecticides in tissues of poisoned fish. Advan Chem Ser 60: 207-218. 
30. Bhattacharya S (2000) Signal transduction by xenobiotics in fish Indian J Exp Biol 38(8): 753-761.

31. Satyanarayan S, Kotangale AS, Verma S (2012) Histopathological changes due to some chlorinated hydrocarbons pesticides in the tissues to Cyprinuscarpio. IOSR Journal of Pharmacy 60-66.

32. Pickering OH, Henderson C, AE Lemke (1962) Toxicity of organophosphorous insecticides to different species of warm water fishes. Tran Am FishSoc 91(2): 175-184.

33. Joseph VK (1989) Effect of Aldrin, an organochlorine compound, on frog, Ranahexadactyla. Ph.D. Thesis, S. V. University, Tirupati, India.

34. Gakstatter JH (1968) Rates of Accumulation of 14C-Dieldrin Residues in Tissues of Goldfish Exposed to a Single Sublethal Dose of 14C-Aldrin. J Fish Res Bd Can 25(9): 1797-1801.

35. Singh NN, Srivastava AK, Srivastava AK (1993) Biochemical changes in the freshwater Indian catfish-Heteropneustesfossilis (Bloch.) following exposure to sublethal concentration of aldrin. J Environ Bio 14(1): 7-12.

36. Ton C, Lin Y, Willett C (2006) Zebrafish as a model for developmental neurotoxicity testing. Birth Defects Research Part A: Clin and Mol Teratol 76(7): 553-567.
37. Jhamtani RC, Shukla S, Dahiya MS, Agarwal R (2017) Aldrin induced Alterations at Endogenous Enzymatic Levels in Zebrafish. $104^{\text {th }}$ Indian Science Congress, Science \& Technology for National Development, Sri Venkateswara University, Tirupati, India.

38. Jhamtani RC, Shukla S, Dahiya MS, Agarwal R (2016) Combined Effects of Aldrin and Titanium Dioxide-NPs in Zebrafish. New Insights and Multidisciplinary Approach in Toxicological Studies, Amity University Uttar Pradesh (AUUP), India.

39. Jhamtani RC, Shukla S, Dahiya MS, Agarwal R (2015) Impact of Titanium Dioxide on Aldrin Toxicity in Zebrafish. "Nanosciences, Nanotoxicology and Nanoinformatics" Present and Future Perspectives, Integral University, Lucknow, India.

40. Muley DV, Kamble GB, Gaikwad PT (1996) Endosulfan toxicity in the freshwater fish Tilapia mossambica. Proc in Acad Environ Biol 5 (1): 49-55.

41. Hodge HC, Boyce AM, Deichmann WB, Kraybill HF (1967) Toxicology and no-effect levels of aldrin and dieldrin. Toxicol and Appl Pharmacol 10: 613-675.

\section{Your next submission with Juniper Publishers will reach you the below assets}

- Quality Editorial service

- Swift Peer Review

- Reprints availability

- E-prints Service

- Manuscript Podcast for convenient understanding

- Global attainment for your research

- Manuscript accessibility in different formats

( Pdf, E-pub, Full Text, Audio)

- Unceasing customer service

Track the below URL for one-step submission https://juniperpublishers.com/online-submission.php 